\title{
Prosedur Penyelenggaraan Bimbingan Teknis Pengelolaan Arsip Dinamis Sebagai Wujud Nyata Pembinaan Kearsipan di Kabupaten Kebumen
}

\author{
Nabila Febriana \\ Sekolah Vokasi, Universitas Gadjah Mada
}

\section{ABSTRACT}

This study aims to determine the procedures for organizing training for managing records. In addition, the authors also describe the condition of records management on the target of technical guidance. Technical guidance on the management of records is organized by Dinas Kearsipan dan Perpustakaan Kabupaten Kebumen. Data collection methods used by the author consist of interviews, participatory observation, and literature study. The data collected was then analyzed using the data triangulation approach. The results of the analysis are then described descriptively. The conclusion obtained from this paper is that the condition of dynamic archive management in technical guidance participants is not in accordance with archival standards, so competency improvement is needed through technical guidance. The procedure for organizing technical guidance for managing dynamic records by Disarpus Kabupaten Kebumen consists of 3 stages, namely preparation, implementation and evaluation.
Submitted: 09/07/2020

Received: 09/08/2020

*Correspondence:

Nabila Febriana

nabilafebriana@mail.

ugm.ac.id

KEYWORDS:

training

records management

archival development

\section{INTISARI}

Penelitian ini bertujuan untuk mengetahui prosedur penyelenggaraan bimbingan teknis pengelolaan arsip dinamis. Selain itu, penulis juga mendeskripsikan kondisi pengelolaan arsip dinamis pada sasaran bimbingan teknis.. Bimbingan teknis pengelolaan arsip dinamis diselenggarakan oleh DInas Kearsipan dan Perpustakaan Kabupaten Kebumen. Metode pengumpulan data yang digunakan penulis terdiri dari wawancara, observasi partisipatif, dan studi pustaka. Data yang dikumpulkan kemudian dianalisis dengan pendekatan triangulasi data. Hasil analisis kemudian diuraikan secara deskriptif. Kesimpulan yang diperoleh dari makalah ini adalah kondisi pengelolaan arsip dinamis pada peserta bimbingan teknis belum sesuai dengan standar kearsipan sehingga diperlukan peningkatan kompetensi melalui bimbingan teknis. Adapun prosedur penyelenggaraan bimbingan teknis pengelolaan arsip dinamis oleh Disarpus Kabupaten Kebumen terdiri dari 3 tahapan, yaitu persiapan, pelaksanaan, dan evaluasi.

KATA KUNCl: bimbingan teknis

pengelolaan arsip dinamis

pembinaan kearsipan

CITE THIS ARTICLE:

Febriana, N. (2020). Prosedur

Penyelenggaraan

Bimbingan Teknis

Pengelolaan Arsip Dinamis Sebagai Wujud

Nyata Pembinaan Kearsipan di Kabupaten Kebumen

. Jurnal Diplomatika, 3 (2), 126-136. 


\section{PENDAHULUAN}

Arsip merupakan "bukti berdirinya dan kepemilikan suatu organisasi secara resmi" (Basuki, 2003). Informasi yang terekam dalam arsip dianggap sesuai dengan fakta dan tanpa rekayasa. Arsip pun dipahami sebagai sekumpulan dokumen yang diciptakan oleh organisasi dan berisi "tindakan, keputusan, dan operasi yang telah terjadi dalam organisasi" (Muhidin dan Winata, 2016, 2). Arsip merupakan aset vital bagi organisasi sehingga pengelolaannya diperlukan keahlian khusus. Keahlian tersebut diperlukan agar fisik maupun isi informasi arsip tetap terpelihara sebab mendapat penanganan yang tepat saat, sebelum, maupun sesudah bencana, sesuai dengan standar dan prosedur yang berlaku di bidang kearsipan. Keahlian tersebut merupakan cerminan dari akumulasi pengalaman dan pengetahuan terkait aspek teknis maupun konsep. Mereka yang dibekali keahlian dalam bidang kearsipan disebut sebagai arsiparis.

Arsiparis, dalam makalah ini, mengacu pada jabatan fungsional di lembaga pemerintahan. Arsiparis juga bertugas dalam menyebarluaskan pemahaman dan kesadaran untuk tertib arsip Kegiatan penyebarluaskan dan sadar tertib kearsipan di lingkungan institusi pemerintah lazim disebut dengan pembinaan kearsipan. Menurut Effendi $(2014,6)$, pembinaan kearsipan merupakan:

"kegiatan untuk memberi pengarahan, penguatan, dan pemberdayaan kepada pencipta arsip, lembaga kearsipan, dan sumber daya manusia (SDM) kearsipan serta pemangku kepentingan lainnya, berkenaan dengan arsip guna mencapai tujuan penyelenggaraan kearsipan secara efektif dan optimal"

Tujuan pembinaan kearsipan adalah memberikan pengarahan, penguatan dan pemberdayaan kepada sumber daya manusia kearsipan. Pengarahan, penguatan, dan pemberdayaan merujuk pada kegiatan penyampaian pemahaman konsep maupun penyampaian aspek teknis dan prosedur dalam mengelola arsip. Institusi yang memiliki kewenangan secara legal dan yuridis dalam pembinaan kearsipan adalah lembaga kearsipan, baik tingkat nasional maupun daerah. Hal tersebut tersurat dalam Undang-Undang Nomor 43 Tahun 2009 tentang Kearsipan pasal 1 ayat 2 bahwa lembaga kearsipan "memiliki fungsi, tugas dan tanggung jawab di bidang pengelolaan arsip statis dan pembinaan kearsipan".

Makalah ini berfokus pada kegiatan bimbingan teknis sebagai salah satu wujud dari pembinaan kearsipan, khususnya yang dilakukan oleh lembaga kearsipan daerah. Dinas Kearsipan dan Perpustakaan Kabupaten Kebumen merupakan salah satu lembaga kearsipan daerah yang bertugas membina setiap organisasi di tingkat Kabupaten Kebumen dalam mengelola arsip sesuai standar dan prosedur kearsipan. Pembinaan kearsipan diwujudkan dalam bentuk bimbingan teknis (selanjutnya disebut bimtek). Kegiatan bimtek kearsipan yang dilaksanakan oleh Disarpus Kabupaten Kebumen difokuskan pada pengelolaan arsip dinamis. Adapun tujuan utama dari bimtek tersebut adalah membantu proses penataan arsip sehingga lebih tertata dan dapat ditemukan kembali ketika dibutuhkan secara cepat, tepat, dan akurat. Selain itu, peserta bimtek juga diberikan pemahaman bahwa seluruh organisasi dibawah binaan Disarpus Kabupaten Kebumen harus melaksanakan pembenahan arsip dan penyerahan arsip bernilai kesejarahan kepada lembaga kearsipan. Adapun kondisi yang diharapkan setelah bimtek kearsipan yaitu kesadaran kearsipan yang lebih meningkat dengan wujud tertib dalam penataan arsip diharapkan, serta dapat membantu kinerja staff dalam penemuan kembali arsip dan proses pengambilan kebijakan, dan mampu memilah informasi yang akurat. 
Berdasarkan latar belakang tersebut, maka pertanyaan penelitian yang diajukan dalam makalah ini adalah bagaimana prosedur penyelenggaraan bimbingan teknis pengelolaan arsip dinamis oleh Dinas Perpustakaan dan Kearsipan Kabupaten Kebumen?

\section{METODE PENELITIAN}

Makalah ini didasarkan pada hasil penelitian yang bersifat kualitatif deskriptif, yaitu mendeskripsikan alur dan prosedur penyelenggaraan bimbingan teknis pengelolaan arsip dinamis di Dinas Kearsipan dan Perpustakaan Kabupaten Kebumen. Data primer dikumpulkan melalui observasi partisipasi dari salah satu penulis dan wawancara tidak terstruktur. Sedangkan data sekunder dilakukan dengan mengkaji berbagai bahan pustaka, baik berupa buku, jurnal, maupun produk hukum. Data tersebut kemudian diolah dengan pendekatan triangulasi data. Data dipilah dan diklasifikasikan terlebih dahulu. Hasil pemilahan kemudian disinkronkan dengan konsep teori pada bahan pustaka. Hasil analisis selanjutnya dinarasikan secara deskriptif.

\section{HASIL DAN PEMBAHASAN \\ Kondisi Pengelolaan Arsip Dinamis Sasaran Bimbingan Teknis}

Arsip merupakan "informasi yang terekam dalam berbagai media untuk menjalankan kegiatan suatu instansi" (Basuki, 2003). Media rekam arsip dapat berwujud konvensional maupun elektronik. Muhidin dan Winata (2016), arsip berdasarkan fungsi dan kegunaannya terdiri dari arsip dinamis (records) dan arsip statis (archive). Adapun definisi arsip dinamis dan arsip statis sebagai berikut:

"Arsip dinamis merupakan arsip yang digunakan dalam kegiatan penciptaan arsip secara langsung dan disimpan selama jangka waktu tertentu, sedangkan arsip statis merupakan arsip yang dipermanenkan dan memiliki nilai kesejarahan yang diverifikasi oleh lembaga kearsipan" (Muhidin \& Winata, 2016, 5). berikut:

Arsip perlu dikelola sesuai standar dan prosedur, dengan tujuannya sebagai

"develop and/or identify standards or procedures for the effective, efficient, and secure management of records and information throughout the organization; provide effective control, appropriate security, and management over the creation, maintenance, use, and disposition of all records within the organization; ensure that the records accurately reflect the business practices, policies, and transaction of the organization; simplify the activities, systems, and process of records creation, maintenance, and use; preserve and dispose of records in accordance with business needs, statutes, and regulations; protect vital records; provide business continuity in the event of a disaster; protect records of historical importance; provide evidences of business, personal, and cultural activity; and maintain corporate, personal, and collective memory" (Franks, 2018, 35).

Pengkategorian arsip dinamis dengan arsip statis, pada dasarnya merupakan konsekuensi logis dari diterapkannya pendekatan lifecycle model dalam pengelolaan arsip. Pada mulanya, pendekatan lifecycle model muncul untuk menyelesaikan permasalahan volume arsip bermedia kertas yang semakin meningkat sehingga perlu dilakukan penyusutan. Selain itu, pendekatan lifecycle model juga dinilai merupakan solusi praktis penyelamatan arsip yang memiliki nilai guna kesejarahan. Pendekatan 
lifecycle model terbagi menjadi dua, yaitu life cycle of records dan life cycle of archives (Basuki, 2003). Berdasarkan Undang-Undang Nomor 43 Tahun 2009 tentang Kearsipan, maka ruang lingkup pengelolaan arsip dinamis, terdiri dari penciptaan arsip, penggunaan arsip, pemeliharaan arsip, dan penyusutan arsip.

Pengelolaan arsip tersebut harus berpedoman pada empat pilar utama kearsipan yang meliputi:

1. Tata naskah dinas, yaitu pengelolaan informasi yang meliputi jenis, media, format, pengamanan, penyediaan, legal, pendistribusian, dan penyimpanan dalam komunikasi kedinasan (Muhidin dan Winata, 2016).

2. Klasifikasi arsip, yaitu pola pengaturan informasi secara sistematis dan logis sebagai dasar pemberkasan arsip (Muhidin dan Winata, 2016).

3. Jadwal retensi arsip, yaitu daftar yang memuat jangka waktu penyimpanan arsip, jenis arsip, dan keterangan yang berisi rekomendasi penetapan arsip musnah atau dipermanenkan. Jadwal retensi arsip digunakan sebagai pedoman dalam penilaian dan penyusutan arsip (Muhidin dan Winata, 2016).

4. Sistem klasifikasi keamanan dan akses arsip, yaitu pengelompokkan arsip yang didasarkan pada dampak yang ditimbulkan terhadap kepentingan dan keamanan negara, publik, maupun perseorangan, untuk kemudian disusun sebagai dasar pengaturan yang melindungi hak dan kewajiban pencipta arsip secara legal serta mempermudah pemanfaatan arsip oleh publik (Muhidin dan Winata, 2016).

Konsep pengelolaan arsip dinamis tersebut juga dilaksanakan oleh SMP Negeri dan puskesmas di Kabupaten Kebumen yang juga peserta bimtek pengelolaan arsip dinamis. Dalam penciptaan arsip, SMP Negeri umumnya berpedoman pada tradisi pengelola senior bidang tata usaha, baik baik dalam pembuatan surat maupun pencatatan. Pencatatan surat menggunakan buku besar atau buku agenda surat masuk dan surat keluar. Arsip yang tercipta antara lain arsip korespondensi, arsip keuangan, arsip kepegawaian, arsip kesiswaan, dan arsip barang investasi miliki daerah (BMD). Adapun penciptaan arsip yang dilakukan di puskesmas berpedoman pada Peraturan Bupati Kebumen Nomor 25 Tahun 2014 tentang Pedoman Klasifikasi Arsip di Lingkungan Pemerintah Kabupaten Kebumen, Peraturan Bupati Kebumen Nomor 26 Tahun 2014 tentang Pengurusan Surat di Lingkungan Pemerintah Kabupaten Kebumen, dan Peraturan Bupati Kebumen Nomor 27 Tahun 2014 tentang Pedoman Penataan Berkas di Lingkungan Pemerintah Kabupaten Kebumen. Sarana pencatatan arsip yang digunakan di puskesmas menggunakan buku agenda. Penggunaan buku agenda hanya untuk surat masuk dan kartu kendali surat masuk, sedangkan surat keluar menggunakan kartu kendali surat keluar. Arsip yang diciptakan seperti surat keterangan sehat, arsip korespondensi, arsip keuangan, dan arsip kepegawaian.

Pada tahap penggunaan dan pemeliharaan meliputi kegiatan "pemberkasan arsip aktif, penataan arsip inaktif, penyimpanan arsip, dan alih media" (Peraturan Pemerintah Nomor 28 Tahun 2012, 2012). Untuk menemukan kembali arsipnya, SMP Negeri dan puskesmas menggunakan buku agenda. Pemberkasan arsip yang dilakukan oleh petugas TU SMP Negeri didasarkan pada jenis dan disimpan pada snalhecter untuk memisahkan dengan arsip lainnya. Snalhecter tersebut disimpan ke dalam rak dokumen. Satu bulan sekali arsip dari snalhecter dipindahkan ke odner dan disimpan di lemari. Penyimpanan arsip di SMP Negeri berada di bidang Tata Usaha dengan jangka simpan lima tahun. Pemberkasan arsip di Puskesmas didasarkan pada jenisnya. Arsip tersebut dimasukkan ke dalam odner. Penyimpanan arsip di puskesmas juga berada di bidang tata usaha. 
Tahap penyusutan arsip terdiri dari kegiatan pemindahan arsip, penyerahan arsip, dan pemusnahan arsip. Pada SMP Negeri, pemindahan arsip dengan retensi 5 tahun, dilakukan dari bagian Tata Usaha ke Gudang. Arsip yang dipindahkan merupakan arsip yang disimpan pada odner, sehingga tidak menggunakan boks untuk sarana penyimpanan ketika di pindahkan. Pemusnahan arsip yang dilakukan SMP Negeri yaitu dengan cara pembakaran dan diperjual-belikan (loak). SMP Negeri belum pernah melakukan penyerahan arsip ke lembaga kearsipan. Adapun di puskesmas, pemindahan arsip dilaksanakan jika sudah lama dan sudah penuh, maka dipindahkan dari odner dan diganti dengan map kertas yang disimpan pada lemari. Lemari tersebut berada di bidang tata usaha. Kegiatan pemusnahan dan penyerahan arsip belum di lakukan.

Kendala yang dihadapi oleh petugas TU SMP Negeri dalam mengelola arsip yaitu adanya rangkap tugas dengan pekerjaan lain sehingga sulit unuk fokus menyelesaikan pengelolaan arsipnya. Sedangkan di puskesmas, petugas arsip sulit dalam penemuan kembali arsip karena pemberkasan masih dikategorikan berdasarkan jenis bukan berdasarkan klasifikasi arsip. Selain itu, petugas TU SMP Negeri dan petugas arsip puskesmas juga belum memahami pedoman berupa jadwal retensi arsip, tata naskah dinas dan jenis dari arsip dinamis, baik arsip aktif, inaktif, maupun arsip vital. Hal tersebut kemudian menjadi latar belakang perlunya pembinaan kearsipan di lingkup puskesmas dan SMP. Pembinaan yang dilakukan oleh Disarpus Kabupaten Kebumen dilakukan melalui bimbingan teknis kearsipan. Bimbingan teknis kearsipan yang diselenggarakan berfokus pada pengelolaan arsip dinamis.

\section{Prosedur Penyelenggaraan Bimbingan Teknis Pengelolaan Arsip Dinamis}

Dalam konsep pengelolaan sumber daya manusia bidang kearsipan, bimbingan teknis kerap diistilahkan sebagai training and development. Franks (2018: 359) menjelaskan bahwa program training atau bimbingan teknis "are shorter in duration, provide participants with a discrete set of skills and knowledge". Pada umumnya, durasi waktu bimbingan teknis cukup singkat antara satu hingga tiga hari. Peserta bimtek lebih difokuskan pada keterampilan dan pengetahuan yang spesifik sesuai dengan permasalahan atau kebutuhan organisasi. Training "menjadi sarana belajar terbaik, yaitu berinteraksi dengan ahli yang professional dan mendapatkan pelatihan secara langsung" (Smith, 2007, 205). Dalam konteks bimtek, pelaksanaannya diharapkan memudahkan peserta dalam memahami teori dan praktik sebab disampaikan langsung arsiparis yang dinliai kompeten dan profesional.

Oleh sebab durasi bimtek yang relatif singkat, maka materi dibuat komprehensif dan menyasar pada permasalahan yang dihadapi para peserta bimbingan teknis. Franks $(2018,370)$ menyebutkan cakupan materi yang dapat disampaikan dalam bimbingan teknis, antara lain:

"definition of records management; key records management laws and regulations; definition and example of electronic records; electronic records management (ERM); steps to safeguard records; personal papers vs corporate records; recordkeeping responsibilities; records retention; records schedules; identifying and managing essential records; managing web records; ethics and behavioral norms"

Adapun bimbingan teknis oleh Disarpus Kabupaten Kebumen, maka cakupan materi yang disampaikan berfokus pengelolaan arsip dinamis, baik konsep maupun praktik. Target sasaran dari bimbingan teknis, secara konsep, dapat dibagi dalam tiga kategori (Smith, 2007, 206), yaitu:

1. Senior managers, atau pemangku kebijakan organisasi. Bimbingan teknis dalam wujud pertemuan atau rapat rutin, dengan menekankan pada materi urgensi dan 
kontribusi pengelolaan arsip bagi keberlanjutan organisasi.

2. Operational staff, atau staf yang berada di unit-unit pengolah arsip. Wujud bimbingan teknik berfokus pada upaya peningkatan kesadaran pentingnya mengelola arsip sesuai standar dan prosedur.

3. Records liaison staff, atau staf yang bertanggung jawab dalam hal kearsipan di suatu organisasi.

Target bimbingan teknis yang diselenggarakan oleh Dinas Kearsipan dan Perpustakaan Kabupaten Kebumen, secara konseptual, dapat dikategorikan sebagai records liaison staff, yaitu pegawai tata usaha dan petugas arsip. Smith $\left(644^{1}, 64^{1}\right)$ mengklasifikasikan menjadi tiga bentuk bimbingan teknis untuk kategori records liaison staff, yaitu:

1. Introductory, berupa sosialisasi setengah hari, dan materi berupa pengantar kearsipan dan penerapannya di lingkungan organisasi. Sesi ini diberikan oleh arsiparis ahli atau manajer rekod.

2. Specialist training, pelatihan full-day atau setengah hari dengan materi lebih spesifik dan disesuaikan dengan permasalahan atau kebutuhan organisasi.

3. Annual event, berupa konferensi tahunan dengan fokus isu-isu terkini mengenai kearsipan.

Bimbingan teknis kearsipan yang diselenggarakan oleh Dinas Kearsipan dan Perpustakaan Kabupaten Kebumen merupakan wujud penggabungan bentuk introductory dengan specialist training. Hal ini dapat dilihat pada cakupan materi yang diberikan, berupa pengantar kearsipan sekaligus pengelolaan arsip dinamis. Adapun tahapan bimbingan teknis, secara konsep, Franks $(2018,371)$ menyebut terdapat lima tahapan, yaitu:

1. Identify purpose (goals and objectives setting), yaitu mengidentiPkasi tujuan dari pelaksanaan bimtek, baik jangka pendek maupun jangka panjang. Tujuan tersebut harus mudah untuk dievaluasi serta realistis sesuai dengan kebutuhan dan harapan dari peserta bimtek;

2. Choose a training method and tools, tiga alternatif metode dan alat yang dapat digunakan, yaitu pelatihan dalam ruang, pelatihan jarak jauh, dan on-the-job training. Pemilihan metode dan alat didasarkan pada kondisi dari penyelenggara maupun sasaran bimtek;

3. Determine delivery method, hal yang perlu diperhatikan dalam penyampaian materi, yaitu pihak yang menyampaikan materi, lokasi pelaksanaan training, durasi pelatihan, serta penyesuaian dengan kondisi sosial psikologis dari peserta training;

4. Motivate employees, penyelenggara maupun organisasi memberikan motivasi kepada peserta yang diikutkan dalam training, misalnya melalui insentif maupun kesempatan untuk mempraktikan hasil bimbingan teknisnya di tempat asal peserta bekerja;

5. Institute review and reporting mechanisms, adanya evaluasi secara rutin, baik dari penyelenggara maupun peserta bimtek.

Adapun tahapan pelaksanaan bimbingan teknis oleh Disarpus Kabupaten Kebumen, berdasarkan penuturan salah satu narasumber, terdiri dari persiapan, pelaksanaan, dan evaluasi.

\section{Persiapan Bimbingan Teknis}

Berdasarkan Rencana Strategis Kerja (Renstra) Disarpus Kabupaten Kebumen 2016-2021, Disarpus Kabupaten Kebumen memiliki kebijakan meningkatkan 
pembinaan dan pengawasan kearsipan dan perpustakaan. Pembinaan yang dilaksanakan oleh bidang kearsipan salah satunya melalui bimbingan teknis kearsipan. Sasaran bimbingan teknis yang telah dilaksanakan sebelumnya yaitu petugas arsip desa, kemudian dilanjutkan dengan sasaran instansi pemerintah lainnya. Pada tahun 2020, sasaran yang dipilih oleh Disarpus Kabupaten Kebumen adalah petugas Tata Usaha SMP Negeri dan petugas arsip puskesmas. Jumlah peserta bimbingan teknis adalah 80 peserta, terdiri dari 49 petugas Tata Usaha SMP Negeri dan 31 petugas arsip puskesmas.

Pemilihan tema bimbingan teknis didasarkan pada materi yang diperoleh peserta pada bimbingan teknis yang pernah diikuti sebelumnya. Peserta dari petugas Tata Usaha SMP Negeri dan petugas arsip puskesmas belum pernah mendapatkan bimbingan teknis sehingga tema yang menjadi prioritas adalah pengelolaan arsip dinamis. Alasan pemilihan tema tersebut adalah SMP Negeri dan puskesmas juga merupakan instansi pencipta arsip yang seharusnya dapat mengelola arsip dinamis.

Tahap berkutnya yaitu mempersiapkan materi untuk presentasi dan penentuan narasumber untuk mendukung terlaksananya bimbingan teknis. Cakupan materi yang dipersiapkan berupa materi kebijakan kearsipan, pengantar kearsipan, tata naskah dinas, pengurusan surat dalam SIKD, pengelolaan arsip inaktif, pengelolaan arsip vital, penyusutan arsip, pengawasan, dan penanganan arsip secara dini dalam menghadapi bencana. Materi kebijakan kearsipan, pengantar kearsipan, pengurusan surat dalam SIKD, pengelolaan arsip inaktif, pengelolaan arsip vital, dan penyusutan arsip disampaikan oleh arsiparis Disarpus Kabupaten Kebumen. Materi tata naskah dinas mengundang narasumber dari Bagian Organisasi Sekretariat Daerah, materi pengawasan dengan narasumber dari inspektorat, dan materi penanganan arsip secara dini dalam menghadapi bencana narasumber dari BPBD Kabupaten Kebumen.

Tahap berikutnya yaitu mempersiapkan administrasi dan acara. Persiapan tersebut dimulai dengan membuat undangan bagi peserta dan narasumber, membuat daftar hadir peserta, mempersiapkan Surat Perintah Perjalanan Dinas (SPPD) bagi pembina bimbingan teknis kearsipan, membuat persyaratan yang harus dipenuhi peserta berupa 2 buah foto resmi, SPPD dari masing-masing instansi, dan membawa komputer jinjing. Kemudian mempersiapkan lay out materi untuk peserta dan fasilitas yang akan didapatkan oleh peserta, berupa cocard, tas bimtek, bolpoin, dan booknote. Selanjutnya pembuatan pretest dan posttest untuk peserta. Persiapan terakhir yaitu pengadaan boks arsip, tali ra $\mathrm{Pa}$ dan kertas samson untuk dibawa pulang peserta sebagai implementasi dari materi bimbingan teknis yang sudah dilaksanakan serta membuat daftar penerimaan sarana arsip tersebut.

\section{Pelaksanaan Bimbingan Teknis}

\section{a. Hari Pertama Bimbingan Teknis}

Peserta melakukan registrasi dengan menandatangani daftar hadir peserta dan mengumpulkan foto. Foto peserta digunakan sebagai tanda pengenal pada cocard dan pada serti 1 ikat kepesertaan. Peserta juga menyerahkan SPPD sebagai bukti kepada pimpinan peserta telah melaksanakan bimtek. Peserta mendapatkan tas, pretest, booknote, bolpoin, co-card dan lay out materi. Peserta memilih tempat duduk sendiri tidak diatur oleh panitia. Peserta langsung menyelesaikan pretest yang telah diperoleh saat registrasi. Hasil dari pretest di tempel di pintu keluar, 
tepatnya di akhir acara oleh panitia.

Acara pertama yaitu pembukaan, menyanyikan lagu Indonesia Raya, dilanjutkan dengan pembacaan doa, dan sambutan Kepala Bidang Kearsipan dan Kepala Dinas. Acara berikutnya berupa pernyataan berupa simbolisasi bahwa peserta dinyatakan resmi mengikuti Bimbingan Teknis Kearsipan oleh Kepala Disarpus Kabupaten Kebumen.

Materi bimbingan teknis di hari pertama, yaitu kebijakan kearsipan, pengantar kearsipan, tata naskah dinas, pengurusan surat dalam SIKD, dan pengelolaan arsip inaktif. Materi kebijakan kearsipan disampaikan oleh Anna Ratnawati, S.KM.,M.Si selaku Kepala Disarpus Kabupaten Kebumen. Cakupan bahasan dari materi tersebut yaitu dasar kebijakan, pengantar umum, dan penyelenggaraan kearsipan Pemerintah Kabupaten Kebumen.

Materi pengantar kearsipan disampaikan oleh Ir. Agus Subekti selaku Sekretaris Disarpus Kabupaten Kebumen. Materi ini memuat dasar yuridis, definisi arsip, penyelenggaraan kearsipan, tujuan penyelenggaraan kearsipan, fungsi arsip dikelola, karakteristik arsip, jenis arsip, pengelolaan arsip, presentase volume arsip, daur hidup arsip, perlindungan dan penyelamatan arsip.

Materi tata naskah dinas dipaparkan oleh Nana dari Bagian Organisasi Sekretariat Kabupaten Kebumen. Berdasarkan Peraturan Bupati Kebumen Nomor 63 Tahun 2014 tentang Tata Naskah Dinas di Lingkungan Pemerintah Kabupaten Kebumen, $\mathrm{Bu}$ Nana menjelaskan tentang pengertian tata naskah dinas, naskah dinas, format, Kop naskah dinas, stempel, papan nama, sampul naskah dinas, Kop sampul naskah dinas, kewenangan penandatanganan naskah dinas, pendelegasian wewenang penandatanganan naskah dinas, perubahan, pencabutan, pembatalan, mandat, dan penandatanganan naskah dinas. Selain pengertian, Nana menjelaskan naskah dinas yang dirumuskan dalam susunan dan bentuk produk hukum serta naskah dinas yang dirumuskan dalam susunan dan bentuk surat. Materi lainnya yang disampaikan yaitu azas naskah dinas, prinsip naskah dinas, penyelenggaraan naskah dinas, tingkat keamanan surat dinas, kecepatan proses, penggunaan kertas, pengetikan naskah dinas, tingkat keaslian, bagian-bagian surat dinas, dan penggunaan bahasa Indonesia di Kantor.

Materi berikutnya adalah pengurusan surat dalam SIKD oleh Putri Wahyu Pengesti, S.S.T. Ars (Arsiparis). Materi tersebut menjelaskan tentang pengertian arsip, jenis arsip dinamis, pengelolaan arsip dinamis aktif, pengurusan surat, pemberkasan, penyusutan arsip dinamis aktif, dan pengelolaan arsip dinamis aktif menggunakan aplikasi SIKD. Peserta juga mempraktikan penggunaan SIKD menggunakan gawai pintar maupun komputer jinjing.

Materi terakhir pada hari pertama bimbingan teknis yaitu pengelolaan arsip inaktif yang disampaikan oleh Galuh Windu Wati, S.S.T.Ars (Arsiparis). Materi ini mendiskusikan pengertian arsip inaktif, tujuan pengelolaan arsip inaktif, sarana dan prasana pengelolaan arsip inaktif, prosedur penataan arsip inaktif, dan tata cara print fisis arsip inaktif. Peserta mempraktikan pengisian kartu fisis, membungkus arsip dengan kertas samson dan tali rafia, input data arsip ke SIKD untuk arsip inaktif, manuver fisik arsip, merangkai boks arsip, dan boxing arsip.

\section{b. Hari Kedua Bimbingan Teknis}

Materi bimtek hari kedua yaitu, pengelolaan arsip vital, penyusutan arsip, pengawasan arsip, dan penanganan arsip secara dini dalam menghadapi bencana. 
Pengelolaan arsip vital disampaikan oleh Endah Wahjoe Widajati, S.Sos,M.Si selaku Kepala Bidang Kearsipan yang menjelaskan tentang pengelolaan arsip vital, fungsi arsip vital, penataan arsip vital, penyimpanan arsip vital, penggunaan arsip vital, kewenangan akses, perlindungan dan pengamanan arsip vital.

Materi berikutnya, yaitu penyusutan arsip oleh Dra. Unik Ganiwati Kasi Pengelolaan Arsip Dinamis. Penyusutan arsip menjelaskan tentang kegiatan pemindahan, pemusnahan, dan penyerahan arsip. Selanjutnya, materi pengawasan dari Inspektorat Kabupaten Kebumen yang memuat audit kearsipan eksternal dan internal, kewenangan pengawasan, kewenangan mengaudit, dan pelaksanaan pengawasan kearsipan. Materi terakhir adalah penanganan arsip secara dini dalam menghadapi bencana oleh BPBD Kabupaten Kebumen.

Setelah sesi materi, peserta mengisi postest dan hasilnya ditempel di pintu keluar seperti hasil pretest. Setelah sesi penutupan bimtek, panitia memberikan boks arsip sejumlah 5 buah, kertas samson, dan tali rafia sebagai bekal menerapkan hasil bimtek di instansi masing-masing.

\section{Evaluasi Bimbingan Teknis}

Evaluasi bimtek dalam hal ini terkait dengan evaluasi terhadap materi yang disampaikan selama bimtek. Apabila peserta dapat menjawab dengan tepat maka bimbingan teknis dapat dikatakan berhasil untuk memberikan pemahaman kepada peserta. Selain itu, diharapkan peserta langsung menerapkan ilmunya setelah bimtek. Apabila peserta bimtek masih memerlukan konsultasi kearsipan, Disarpus Kabupaten Kebumen memfasilitasi melalui group di WhatsApp sebagai sarana komunikasi apabila peserta memiliki kendala di instansi. Jika bimtek dirasa masih belum maksimal dalam menjawab permasalahan, instansi dapat mengajukan pendampingan untuk penataan arsip.

\section{Kendala Bimbingan Teknis Pengelolaan Arsip Dinamis}

Kendala yang dihadapi dalam hal penyelenggaraan bimtek oleh Disarpus Kabupaten Kebumen adalah pelaksanaan belum tepat waktu dan kurang adanya koordinasi antar panitia sehingga durasi untuk narasumber terlalu lama. Pada aspek materi, pemateri melewatkan sesi praktikum untuk pemanfaatan sarana berupa map gantung dan kegunaannya dalam 6illing cabinet. Adapun terkait materi pengawasan seharusnya disampaikan untuk peserta yang telah melakukan pengelolaan arsip dinamis secara utuh di instansi. Adapun terkait pretest dan posttest bagi peserta, sebaiknya dilakukan sinkronisasi antara bentuk pertanyaan dengan materi yang diberikan agar tidak terjadi salah tafsir. Pertanyaan yang mengacu tentang kondisi arsip di instansi, menjadi salah satu dasar untuk materi yang akan disampaikan. Adapun jawaban tentang kendala yang dihadapi oleh setiap instansi juga menjadi pedoman Disarpus Kabupaten Kebumen untuk memberikan solusi yang dapat langsung diterapkan di institusi masing-masing peserta bimtek.

\section{KESIMPULAN}

Penyelenggaraan bimtek pengelolaan arsip dinamis oleh Disarpus Kabupaten Kebumen terdiri dari tiga tahap, yaitu persiapan, pelaksanaan, dan evaluasi. Tahap persiapan berupa mempersiapkan kebutuhan bimtek. Tahapan tersebut terdiri dari, penentuan sasaran bimtek, pemilihan tema bimtek, penyusunan materi bimtek, serta administrasi dan acara. Sasaran bimbingan teknis didasarkan pada Rencana Strategis Kerja (Renstra) Disarpus Kabupaten Kebumen 2016-2021, sehingga sasaran yang 
disepakati adalah petugas Tata Usaha SMP Negeri dan petugas arsip puskesmas, dengan jumlah 80 peserta, terdiri dari 49 petugas Tata Usaha SMP Negeri dan 31 petugas arsip puskesmas. Tema bimbingan teknis kearsipan adalah pengelolaan arsip dinamis karena peserta belum pernah mendapatkan bimbingan teknis terkait pengelolaan arsip dinamis dan sebagai instansi pencipta arsip sudah seharusnya dapat mengelola arsip dinamis. Adapun materi yang dipersiapkan berupa materi kebijakan kearsipan, pengantar kearsipan, tata naskah dinas, pengurusan surat dalam SIKD, pengelolaan arsip inaktif, pengelolaan arsip vital, penyusutan arsip, pengawasan, dan penanganan arsip secara dini dalam menghadapi bencana. Persiapan yang terakhir adalah persiapan administrasi dan acara, yaitu membuat undangan bagi peserta dan narasumber, daftar hadir peserta, foto peserta, SPPD, lay out materi, komputer jinjing, fasilitas untuk peserta berupa tas, co-card, bolpoin, dan booknote, pemilihan tempat bmbingan teknis, mempersiapkan pretest dan posttest, dan mempersiapkan boks arsip, tali rafia dan kertas samson.

Setelah tahapan persiapan, dilanjutkan dengan tahapan pelaksanaan bimbingan teknis pengelolaan arsip dinamis. Tahapan pelaksanaan sebagai berikut, registrasi peserta dan pengumpulan SPPD dari peserta ke pelaksana sebagai bukti kepada pimpinan peserta telah melaksanakan bimtek. Pembagian tas, booknote, bolpoin, cocard dan lay out presentasi materi. Tahapan pelaksanaan memuat pembahasan materi dan praktikum yang disampaikan oleh narasumber dan arsiparis. Tahapan selanjutnya yaitu evaluasi berupa hasil dari pretest dan posttest yang menjadi dasar evaluasi, bahwa peserta dapat memahami materi.

Adapun kendala yang dihadapi pada kegiatan bimtek pengelolaan arsip dinamis oleh Dinas Kearsipan dan Perpustakaan Kabupaten Kebumen, yaitu kurang tepat waktu dalam pelaksanaan, kurang koordinasi antar panitia sehingga durasi narasumber melebihi batas yang ditentukan, pemateri melewatkan sesi praktikum terkait sarana kearsipan, materi pengawasan yang kurang sesuai dengan peserta bimtek, dan masih belum sinkronnya antara bentuk pertanyaan dengan materi untuk tes.

\section{DAFTAR PUSTAKA}

Basuki, Soelistyo. (2003). Manajemen Arsip Dinamis Pengantar Memahami dan Mengelola Informasi dan Dokumen. Jakarta: PT Gramedia Pustaka Utama.

Dawson, Catherine. (2009). Introduction to Research Methods a Practical Guide for Anyone Undertaking a Research Project Fourth Edition. Oxford, United Kingdom: How To Books.

Duranti, Luciana \& Franks, Patricia C. (2017). Encyclopedia of Archival Science. London: Rowman \& Littlefield

Franks, Patricia C. (2018). Records and Information Management: Second Edition. United States of America: American Library Association.

Moleong, Lexy J. (2014). Metodologi Penelitian Kualitatif Edisi Revisi . Bandung: Remaja Rosdakarya.

Muhidin, Sambas Ali \& Winata, Hendri. (2016). Manajemen Kearsipan untuk Organisasi Publik, Bisnis, Sosial, Politik dan Kemasyarakatan. Bandung: Pustaka Setia.

Smith, Kelvin. (2007). Public Sector Records Management Apractical Guide. United States of America: Ashgate Publishing Company.

Hardiwardoyo, Syauki. (2014). Modul 7: Manajemen Kearsipan di Indonesia. 
Tangerang: Universitas Terbuka.

Peraturan Kepala Arsip Nasional Republik Indonesia Nomor 22 Tahun 2012 tentang Desain Pembinaan Kearsipan pada Pemerintah Daerah

Peraturan Bupati Kebumen Nomor 74 Tahun 2017 tentang Tata Naskah Dinas Elektronik di Lingkungan Pemerintah Kabupaten Kebumen

Peraturan Bupati Kebumen Nomor 25 Tahun 2014 tentang Pedoman Klasifikasi Arsip di Lingkungan Pemerintah Kabupaten Kebumen

Peraturan Bupati Kebumen Nomor 26 Tahun 2014 tentang Pengurusan Surat di Lingkungan Pemerintah Kabupaten Kebumen

Peraturan Bupati Kebumen Nomor 27 Tahun 2014 tentang Pedoman Penataan Berkas di Lingkungan Pemerintah Kabupaten Kebumen

Peraturan Pemerintah Nomor 28 Tahun 2012 tentang Pelaksanaan Undang-Undang Nomor 43 Tahun 2009

Undang-Undang Nomor 43 Tahun 2009 tentang Kearsipan 